\title{
The Amazonification of Healthcare Will be the Next Step Forward for Patient Safety
}

\section{Salvador Gullo Neto ${ }^{1,2 *}$}

${ }^{1}$ Assistant Professor at the School of Medicine PUCRS, Brazil

${ }^{2}$ Visiting Faculty at School of Nursing, San Diego State University, SDSU, San Diego, California, USA

*Corresponding Author: Salvador Gullo Neto, Assistant Professor at the School of Medicine PUCRS, Brazil.

We are living in a different world. It was a few years ago when I realized and truly understood the impact of the exponential technologies in our lives [1]. Industry 4.0 is the new reality and we are facing a huge transformation in our society. All industry sectors are being impacted from transportation, communication, finance, hospitality, e-commerce, media, and more. Every day new companies are emerging, reinventing the way people get connected or do business. The most amazing feature of this transformation is the speed of how it happens and how quickly people adopt new products and services.

All this transformation has been possible because technology enables us to make things happen; but there is much more on the table. There is a new way, and a new mindset, to think about business and relations. If you take a deeper look on these new businesses, you will see a different way to run companies. Organizations are becoming less hierarchical, empowering their employees to innovate and to establish a new relationship with their customers. Customers' experience is the new mantra. Amazon, Uber, Airbnb, Waze, Yelp and other new tech-companies did that and their impact on each sector was notable. They simply replaced the old business model established for many years with a new one based on customer needs.

Some authors use the term "amazonification" [2] to describe this innovative new approach to selling, delivering, and providing customer services. Establishing a straight connection with your customer gives you an opportunity to redesign your business with them and for them.

And, what about healthcare? Why is taking so long for these changes to happen in healthcare. Is healthcare any different?

Indeed, we have been more conservative than the other industries and it's taking longer for this transformation to become more tangible. However, there is no doubt that is coming! All of these new technologies using artificial intelligence, virtual reality, cloud computing, Internet-of-things, social media and other tools are being tested in healthcare and soon we will be applied in an extensive way. What I think is harder to change about our sector is the mindset. Historically, healthcare is super hierarchical and very skeptical on major innovative approaches.
Personally, I've been trying to understand how we can use these new tools to maximize our efforts on patient safety. According to the Patient Safety Movement Foundation, around 200,000 Americans will die this year at USA hospitals due to medical errors and there hasn't been much improvement in the last few years [3]. Most of the experts in the field support the idea that engaging patients and their families is a key point to reduce adverse events; but until now, hospitals haven't been very successful on this topic. All the traditional approaches work for a limited length of time with lowto-mild impact.

When looking at the examples of transportation and lodging, we saw that industry was remodeled since customer experience. Technologies took place and I ask myself, why can't we apply the same methodology on healthcare? If a patient's health and safety is our main reason to work, why is it so difficult to have a system built on patient safety experience? Can you imagine all the healthcare providers rebuilding their facilities using patient experience as the main driver? Why don't we treat our patients as team members and let them truly be part of their treatment, including the possibility to share the responsibility for all the safety concerns that we have?

I know there are many reasons to explain this, a few just mentioned above. At the same time, I'm committed to find a different way to deliver healthcare. I do believe that our sector will face a massive transformation on the next upcoming years based on patient experience and the use of this new technologies. These will help us to do it in a better and faster way, especially regarding patient safety strategies.

The amazonification of healthcare is reality and it is our duty, as healthcare professionals, to understand the best way to apply technology to achieve better results. Our highest impact achievement in innovation, quality, and safety will be using exponential technologies to track patient experience on patient safety and use this information to rebuild healthcare. This article is a combination of an invitation and advice. If we don't accept this challenge, someone else from other sectors will do it - and will do it very soon.

\section{Funding}

No funding. 


\section{Conflict of Interest}

None.

\section{Bibliography}

1. Ismael S., et al. "Exponential Organizations". Diversion Publishing Corporation (2014).

2. Jeff Desjardins. "The Amazonification of Healthcare” (2018).

3. Study Suggests Medical Errors Now Third Leading Cause of Death in the U.S.

\section{Assets from publication with us}

- Prompt Acknowledgement after receiving the article

- Thorough Double blinded peer review

- Rapid Publication

- Issue of Publication Certificate

- High visibility of your Published work

Website: www.actascientific.com

Submit Article: www.actascientific.com/submission.php

Email us: editor@actascientific.com

Contact us: +919182824667 